\title{
Views of Students on Islamic Financial Technology: A Study on State Universities in Bandung
}

\author{
Egi Arvian Firmansyah \\ Universitas Padjadjaran, Bandung, Indonesia \\ email: egi.firmansyah@unpad.ac.id \\ Umar Ibrahim Manaf \\ Universitas Padjadjaran, Bandung, Indonesia \\ email: umaribrhmnf@gmail.com
}

\begin{abstract}
Fintech has developed into a new paradigm with great potential worldwide, including in Indonesia. Angsur is one of the Islamic fintech firms with university students as its target market. This study uses primary data obtained through a questionnaire disseminated to 316 undergraduate economics and business students at three state universities in Bandung. We selected Bandung as it is also known as an educational city with many wellknown universities. This study uses the Mann-Whitney test to identify the mean difference in knowledge of Islamic fintech products and Angsur brand awareness of students based on age, gender, university, and monthly expenses. In addition, we use multiple linear regression to investigate the influence of demographic factors on Islamic fintech product knowledge and Angsur brand awareness. The result of this study shows that only university origin has a significant difference in Angsur brand awareness. Demographic factors do not affect respondents' knowledge about Islamic fintech products and Angsur brand awareness. Besides, the knowledge about Islamic fintech products and Angsur brand awareness is still relatively low. Materials or courses about Islamic fintech are not available in the academic syllabus of the respondents. Thus, to improve the Islamic financial literacy of university students, it is necessary to add Islamic economic materials to the curriculum at the university level.
\end{abstract}

Keywords: Angsur; Brand Awareness; Difference Test; Impact, Islamic Fintech; Product Knowledge

\begin{abstract}
Abstrak: Fintech telah tumbuh dan berkembang menjadi paradigma baru dengan potensi yang besar di seluruh dunia, termasuk di Indonesia. Angsur merupakan salah satu perusahaan fintech Syariah dengan target pasar mahasiswa. Penelitian ini menggunakan data primer yang didapat melalui kuesioner terhadap 316 mahasiswa sarjana di fakultas ekonomi dan bisnis di tiga perguruan tinggi negeri di Kota Bandung. Kota Bandung juga dikenal salah satunya sebagai kota pendidikan dan banyak perguruan tinggi negeri ternama. Penelitian ini menggunakan statistik deskriptif untuk melihat tingkat pengetahuan produk fintech Syariah dan kesadaran merek Angsur mahasiswa dan opini mahasiswa terhadap materi fintech Syariah dalam silabus
\end{abstract}

Economica: Jurnal Ekonomi Islam - Volume 11, Nomor 1 (2020) 
Egi Arvian Firmansyah and Umar Ibrahim Manaf

perkuliahan. Penelitian ini menggunakan uji Mann-Whitney untuk melihat perbedaan rata-rata pengetahuan produk fintech Syariah dan kesadaran merek Angsur mahasiswa berdasarkan usia, jenis kelamin, asal universitas, dan pengeluaran per bulan. Kami menggunakan regresi linear berganda untuk melihat pengaruh faktor demografis terhadap pengetahuan produk fintech Syariah dan kesadaran merek Angsur mahasiswa. Hasil penelitian menunjukkan bahwa hanya asal universitas yang memiliki perbedaan yang signifikan terhadap kesadaran merek Angsur. Faktor demografis tidak berpengaruh terhadap pengetahuan produk fintech Syariah dan kesadaran merek Angsur mahasiswa. Tingkat pengetahuan produk fintech Syariah dan kesadaran terhadap merek Angsur masih rendah, dan pelajaran tentang fintech Syariah tidak terdapat dalam silabus akademik perkuliahan. Sehingga, untuk meningkatkan literasi keuangan Syariah para mahasiswa, diperlukan edukasi dan penambahkan materi ekonomi Syariah dalam kurikulum di berbagai perguruan tinggi.

Kata Kunci: Angsur; Fintech Syariah; Kesadaran Merek; Pengaruh; Pengetahuan Produk; Uji Beda 
Views of Students on Islamic Financial Technology ...

\section{Introduction}

Fintech or financial technology has appeared and developed into a new paradigm after the global financial crisis in 2008 (Arner, Barberis, and Buckley 2015). The global financial crisis in 2008 has brought the global financial system into a widening chasm, leading to the chaotic circumstance of major financial institutions in the United States and worldwide. As a result, many of them asked for their government bailout, indicating their weak capabilities in mitigating the risks.

Financial institutions have undergone significant changes in their behavior by avoiding risks. As a result, financial innovation has been the part of many smaller financial start-up companies and large technology enterprises with no financial burden and regulation load (Chen 2018). In addition to the global financial crisis, the emerging new technologies have provided mobility, ease of use, and speedy delivery of financial services at a lower cost and popular approach (Anikina et al. 2016). Besides, the shift of digital transformation caused by new technology has changed consumer expectations and desires.

Today, customers want banks or other financial services to be accessible anywhere and anytime, whether at home, in the morning, or night. The digital consumer behavior has set new standards for the various service industries, where the industries strive to fulfill the digital consumer mindset using Omni channels and high-tech. It has resulted in intense competition between traditional financial institutions and fintech platforms providing consumercentered services (Dharmesh 2016).

According to the report released by Kynveld Peat Marwick Goerdeler (KPMG), Indonesia has the most profitable banks globally. The average Net Interest Margin (NIM) of the banking industry in Indonesia was $5.7 \%$, and the loan growth or Compound Annual Growth Rate (CAGR) was around 15\% from 2011 to 2016. In May 2017, Bank Central Asia (BCA) became ASEAN's most

Economica: Jurnal Ekonomi Islam - Volume 11, Nomor 1 (2020) 
valuable bank in terms of market capitalization, and in 2015, among other significant banks in ASEAN, Bank Rakyat Indonesia (BRI) had the highest return on capital (ROC) and Asset (ROA) of $49.46 \%$ and $4.46 \%$. However, Indonesia is a country with a high unbanked population. It means, many people do not possess a bank account or do not have access to the bank. Thus, the government of Indonesia was determined to develop financial inclusion by creating opportunities for both traditional financial institutions and emerging performers, namely fintech firms (KPMG 2017).

As in many parts of the world, fintech is one of the rapidly growing sectors in Indonesia. A popular fintech product in Indonesia is commonly known as a mobile payment product (m-payment). Many popular fintech products were developed by big banks, cellular network operators, securities, and brokerage companies, such as Sakuku by BCA bank, Jenius by BTPN bank, t-Cash by Telkomsel, Go-Jek Credit by Go-Jek, and many other products (Teja 2017).

The role of fintech in Indonesia has become essential year by year. According to Bhima Yudhistira, an economist at INDEF (Institute for Development of Economics and Finance), the channeling of fintech credit in 2018 reached IDR 7.6 trillion, channeled to many trading and agricultural sectors. The existence of fintech is considered to improve the Indonesian economy on a macro scale. It can be seen from the household consumption that increased up to IDR 8.49 trillion due to fintech companies' transactions. It is predicted that fintech could increase Indonesia's gross domestic product (GDP) by IDR 25.97 trillion, either directly or indirectly (Laucereno 2018).

Indonesia has a promising Islamic fintech prospect (Firmansyah and Anwar 2019). Fintech has a vast potential to fulfill the urgent needs of Indonesian people that traditional financial institutions cannot provide. Financial Services Authority (OJK), a financial regulator in Indonesia, has issued a legal umbrella for the fintech industry; The OJK Regulation Number 77/POJK01/2016, on lending borrowing services based on Information 
Technology. This regulation was issued at the end of December 2016 (Rusydiana 2018).

Furthermore, regarding Islamic fintech, the Indonesian Ulema Council (MUI) issued a fatwa No 117/DSN-MUI/II/2018 on Information Technologybased Financing Services through its national sharia board, which comply with the Sharia Principles. This fatwa states that Information Technologybased financing services which comply with Sharia principles are the financial services that connect financing service providers with the receiver of this financing through the electronic system using the Internet services (DSN-MUI 2018).

The Islamic or Sharia-compliant services meant in that decree is in line with surah Al-Baqarah: 275, "But Allah has permitted trade and has forbidden interest..." (Departemen Agama RI 2007). The success of Indonesia being the first rank in the global halal food market, as reported by the Global Islamic Economy Report, suggests that the use of digital technology through Islamic fintech also has a significant opportunity to expand the Islamic finance market. Thus, Islamic finance inclusion will also improve. Besides boosting Islamic finance inclusion, the broad scope of Islamic fintech implementation can also provide the opportunity to develop other Sharia-compliant businesses (Sandy 2018).

Based on the Global Islamic Fintech Report data, there were approximately 241 Islamic fintech companies worldwide. Of that number, $25 \%$ of Islamic fintech firms were located in South-East Asia, $24 \%$ in the MENA region, 21\% in Europe, and the rest in other countries (DinarStandard 2021). Head of the Indonesian Islamic fintech association (AFSI), Ronald Yusuf Wijaya, explained that the regulator has well-supported the growing Islamic fintech. Therefore, OJK does not limit the number of listed fintech firms. As long as the firms meet the applicable requirements in POJK Number 77 of 2016, they will operate in Indonesia. 
Egi Arvian Firmansyah and Umar Ibrahim Manaf

Compared to Malaysia as another Muslim-populated country, Malaysian regulators only produce approximately six licenses each year. Of the six fintech companies in Malaysia, only one listed fintech company was licensed by the regulator. By the end of June 2018, among 64 peer-to-peer (P2P) fintech firms, three Sharia-based companies were listed in OJK, namely PT Ammana Fintech Syariah, PT Dana Sharia Indonesia, and PT Investra Radhaka Jaya. In this regard, Indonesia is considered one of the most prepared countries in developing the Islamic fintech sector (Hidayat 2018).

In mid-December 2018, it was reported that there were Islamic fintech firms listed in OJK exceeding the targets of their loan distribution. These two firms were PT Dana Syariah Indonesia and PT Ammana Fintech Syariah that have disbursed financing (loans) of IDR 70 billion and IDR 7 billion, respectively. As of December 2018, the Islamic fintech firms listed in AFSI reached 60 companies, consisting of $\mathrm{P} 2 \mathrm{P}$ lending, payment, aggregator, and ecommerce companies. Of the 60 AFSI members, two P2P Islamic fintech firms were listed in $\mathrm{OJK}$, and nearly ten others were on the stage of the document management process in OJK (Qolbi 2018).

Though fintech has grown and has vast potential, it also faces various risks. According to Widyo Gunadi (2019), the advisor of the Digital Financial Innovation Group of OJK, the risks of fintech companies can be divided into four groups, namely system, data, product, and consumer. These can be translated into system, transaction, and system security failures. Data security, data confidentiality, and data backup are included in data risks. In terms of product risk, fintech firms face high-interest rates and incorrect product information.

In contrast, the customer risks of fintech firms include the application of KYC (know your customers), the handling of complaints, and the lack of product understanding. Furthermore, the Islamic fintech sector in Indonesia faces several other challenges. Among others are the intricate registration process and lack of Islamic finance and banking education of the community. 
Moreover, according to AFSI, fintech has not been fully understood by the general public (Hidayat 2018).

Partnering with North Sumatera State Islamic University (UINSU), OJK has formulated strategic ideas by involving students as education and literacy agents to encourage and enhance local society's literacy and education functions. The concepts of this partnership program include implementing the Training for Trainers (ToT) on financial inclusion for students who will conduct internship programs, having a monthly lecture on issues of the latest financial services industry, and a student internship at OJK KR5 Sumbagut (Wahyudi 2017). This partnership was based on the results of the National Survey on Literacy and Financial Inclusion (SNLIK) conducted by OJK in 2016, stating that from $67.8 \%$ of the people using financial products and services, only $29.7 \%$ of them had adequate knowledge, skills, and trust in the product and financial services. Besides, the students and college students with a financial inclusion rate of $64.2 \%$ also have a financial literacy rate of $23.4 \%$, which is a low score (Bachdar 2018).

As a result of the innovation in financial service products, fintech is a fastgrowing sector supported by the explosion in mobile phone penetration, where $70 \%$ of mobile phones were used to access the Internet (Rusydiana 2018). Based on the survey conducted by the Association of Internet Service providers of Indonesia, there were 143.26 million Internet users in Indonesia, which made up to $54.68 \%$ of the total population of 262 million people (APJII 2017). That figure significantly grew because the number of Internet users in 2016 was 132.7 million, and in 2015 was 110.2 million people. Of the 143.26 million Internet users in 2017, 58.08\% of them were the population of Java Island. The following table is data of Internet user composition in 2017 based on a population area. 
Egi Arvian Firmansyah and Umar Ibrahim Manaf

Table 1. Internet user composition by region

\begin{tabular}{clc}
\hline No. & Region & Internet user composition \\
\hline 1 & Java & $58.08 \%$ \\
2 & Sumatera & $19.09 \%$ \\
3 & Kalimantan & $7.97 \%$ \\
4 & Sulawesi & $6.73 \%$ \\
5 & Bali-Nusa & $5.63 \%$ \\
6 & Maluku-Papua & $2.49 \%$ \\
\hline
\end{tabular}

Source: APJII (2017)

Based on data from the Ministry of Communications and Informatics of the Republic of Indonesia, 53.60\% of millennial generations (16 to 35 years old) use the Internet for e-commerce (Kementrian Komunikasi Dan Informatika RI 2017). In shopping using e-commerce, there is one brand offering installment service, namely Angsur. Angsur is an Islamic fintech firm whose target market is college students, and they are included in the millennial generation. The primary service provided by Angsur is Shariacompliant installment access for Indonesian students. Based on the Angsur web page explanation, customers can use installment services without having a credit card. Angsur applies a buying-selling contract (murabahah), complying with the Sharia principles because it is free from usury (riba). Angsur claims that its services bring social and educational values by offering Sharia-compliant financial solutions to college students in Indonesia. Angsur is expected to increase the number of Islamic fintech customers from the segment of college students. It is in line with one of the OJK's programs, namely involving college students as educational agents for promoting financial services in society (Maudhody 2017). For this reason, this research employs the brand Angsur because it is one of the Islamic fintech companies that focuses on university students as its target market. 
Related to Sharia fintech product, Lantara \& Kartini (2016) employed undergraduate and graduate students of Gadjah Mada University to investigate the difference and influence of demographic factors on student financial literacy. In addition, Che-ha, Hamzah, Sukor, Said, \& Veeriah (2017) employed bank consumers in a state university in Malaysia to explore the difference in consumer awareness about sharia-compliant products based on several demographic factors.

In contrast to the previous research, this present study first describes the knowledge level about fintech products and brand awareness. This study uses Rasch analysis, regression, and Mann-Whitney test and examines undergraduate students (S1) of faculty of economics and business at three state universities in Bandung as the research sample. The authors chose Bandung as one of the educational cities in Indonesia. Bandung has many universities and some state universities famous in the society. Second, this research investigates the mean difference in knowledge about Islamic fintech products and brand awareness of respondents based on age, gender, university origin, and monthly spending. Third, this research investigates whether age, gender, university origin, and monthly expenditures affect respondents' knowledge about Islamic fintech products and Angsur brand awareness. Finally, this study describes respondents' opinions about the Islamic finance material in their university curriculum or syllabus. This section is expected to be an input in the management of higher education institutions for improving Sharia financial literacy among students. The framework of this research can be illustrated in the figure as follows: 
Figure 1. Research framework

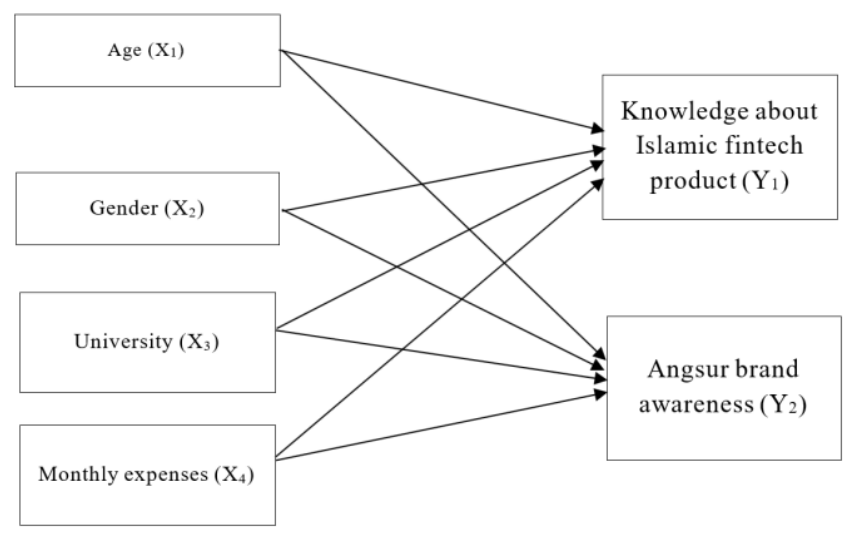

\section{Literature review}

\section{Financial technology}

Financial technology, abbreviated as Fintech, comes from two complementary fields, i.e., services and financial solutions based on advanced technology. Economic literature does not agree with a single popular definition of fintech due to the wide variety of businesses (Nicoletti 2017). Oxford Dictionaries defines fintech as a computer program and other technologies used to support or enable banking and financial services (Oxford Dictionaries, n.d.). Etymologically and financially, according to Mohamed \& Ali (2019), fintech is like a suitcase containing financial technology, referring to a new fast-growing financial service sector that financial institutions very much need. It also constantly affects how technology can support banking and financial services. According to Kalmykova \& Rconviniently (2016), fintech is the economic sector where companies offer different financial services using new technology to create a more efficient process and easier customer access. In comparison, the department of consumer protection of OJK (2017) defines fintech or financial technology as utilizing information technology to improve and develop services in the financial industry. 
Table 2. Fintech types across the world

\begin{tabular}{|c|c|c|c|c|c|c|}
\hline \multirow{2}{*}{$\begin{array}{l}\text { Category } \\
\text { Payment } \\
\text { and transfer }\end{array}$} & \multicolumn{6}{|c|}{ Type of fintech } \\
\hline & $\begin{array}{l}\text { E-commerce } \\
\text { payment }\end{array}$ & $\begin{array}{l}\text { Mobile } \\
\text { banking }\end{array}$ & $\begin{array}{l}\text { Mobile and } \\
\text { online wallet }\end{array}$ & $\begin{array}{l}\mathrm{P} 2 \mathrm{P} \text { payment } \\
\text { and transfers }\end{array}$ & $\begin{array}{l}\text { Digital/virt } \\
\text { currencies }\end{array}$ & \\
\hline $\begin{array}{l}\text { Alternative } \\
\text { lending and } \\
\text { financing }\end{array}$ & $\begin{array}{l}\text { Crowdfunding } \\
\text { based, equity b } \\
\text { donation based } \\
\text { based) }\end{array}$ & $\begin{array}{l}\text { reward } \\
\text { hed, } \\
\text { hybrid }\end{array}$ & $\begin{array}{l}\text { Alternative } \\
\text { lending (online } \\
\text { balance sheet } \\
\text { lending, P2P } \\
\text { lending, } \\
\text { agonistic lender } \\
\text { marketplace) }\end{array}$ & $\begin{array}{l}\text { Emerging/ } \\
\text { developing }\end{array}$ & $\begin{array}{l}\text { Invoice fina } \\
\text { supply chair }\end{array}$ & $\begin{array}{l}\text { ng and } \\
\text { nance }\end{array}$ \\
\hline Others & Robo Advisor & Blockchain & Insurance & $\begin{array}{l}\text { Information } \\
\text { and feeder } \\
\text { site }\end{array}$ & $\begin{array}{l}\text { Aggregator } \\
\text { account }\end{array}$ & $\begin{array}{l}\text { Online } \\
\text { trading/ } \\
\text { capital } \\
\text { market }\end{array}$ \\
\hline
\end{tabular}

Source: OJK (2017)

As the technology develops and progresses, many fintech firms have emerged in various types. Numerous companies have competitively launched innovative products and financial services using active technology. The kinds of fintech which have developed worldwide are as follows (OJK 2017):

\section{Islamic fintech}

Etymologically, Islamic fintech is the incorporation of technology and Islamic finance. From this combination, it can be defined that every product offered by a fintech company must be following the teaching of the Qur'an and sunnah or must be compatible with Sharia. By using the fintech label, the Islamic fintech services are distributed digitally through an innovative digital line referred to as omnichannel. Islamic fintech also plays a role in improving financial inclusion, poverty eradication, and social justice. Islamic fintech enables greater access to Sharia financial services in a simpler, lower and efficient way for providing financing, payment, and investment opportunities suitable with the Maqasid Al-sharia (Rohmati, Anggraini, and Widiastuti 2018; Wasyith 2017; Mohamed and Ali 2019). 
Egi Arvian Firmansyah and Umar Ibrahim Manaf

The Indonesian Ulema Council (MUI) has recently issued several fatwas on the Islamic fintech: First, Fatwa No: 116/DSN-MUI/IX/2017 about Shariacompliant electronic money. In this fatwa, it is clear that sharia-compliant electronic money is electronic money that is in line with Sharia principles (must be free from riba, gharar, maysir, tadlis, risywah, and israf). Contract between parties in the transaction is Wadi'ah or Qardh, Ijarah, Ju'ah, and Wakalah bi al-ujrah (Dewan Syariah Nasional 2017). Second, Fatwa No: 117/DSN-MUI/II/2018 regarding Information Technology-based Financing Services, which are Sharia-compliant. This fatwa stipulates the definition of the services as outlined earlier. Sharia principles view that the financial services offered must be free from usury, gharar, maysir, tadlis, and dharar. The services in this category include factoring, purchase order, online seller, payment gateway, employee financing, and community-based financing. The sharia contracts or akad that can be used for the services included are wakayah bi al-urah, qardh, murabahah, musyaryeah or mudharabah, and ijarah (DSN-MUI 2018).

\section{Product knowledge}

Product knowledge has gained increased attention in the research of consumer behavior (Chang 2004). According to Sumarwan (2011), product knowledge collects various product categories, including brands, product terminology, attributes or product features, product price, and product trust. Brucks (Brucks 1985) states that product knowledge is based on memory or knowledge that the customers possess. According to Lin and Zhen, product knowledge is dependent on consumer awareness or understanding of a product or customer's confidence with it (Lin and Chen 2006). Product knowledge is divided into three categories (Brucks 1985): Subjective Knowledge, knowledge on to what extent someone knows the product; Objective Knowledge, the size and type of information available in one's memory; Experience-based Knowledge, the size of individual experiences in purchasing and using a product. 
Views of Students on Islamic Financial Technology ...

\section{Brand awareness}

Brand awareness is the ability of a brand to appear in consumers' minds when they think of a product category and how easy it is to name it (Shimp 2003). According to Keller (2013), brand awareness is the ability of a brand to stay in consumer memory, where consumers can identify brands based on brand elements such as brand name, logo, character, packaging, and brand taglines. Brand awareness can be measured through the following levels (Durianto, Sugiarto, and Budiman 2004): Unaware of the brand, and It is a state where the customers are unaware of the brand. In the brand awareness pyramid, this situation is at its lowest level; Brand Recognition. Brand recognition is when branding recognition reappears in the consumers' minds after being given a clue or aided recall. Brand recognition is the minimum level of brand awareness; Brand Recall, Brand recall is when consumers can recall the brand without any help or aided memory; Top of mind, Top of mind is the brand that first appears in customers' sense. Top of mind also means that from several brands available in the mind of customers, that one brand is the primary brand.

The following Pyramid, as shown in figure 2. can be used to understand brand awareness level in a more informative way

Figure 2. Brand Awareness Pyramid

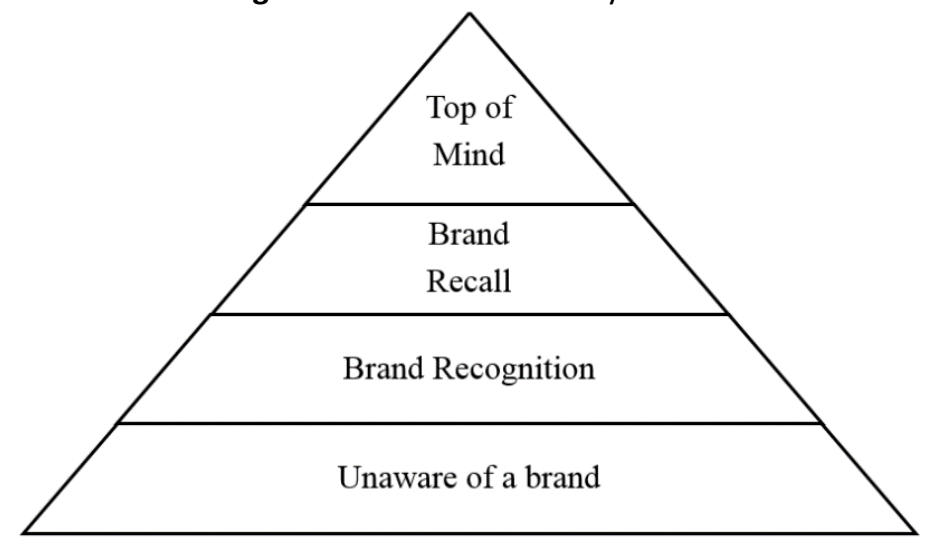

Source: (Aaker 1997; Durianto, Sugiarto, and Budiman 2004)

Economica: Jurnal Ekonomi Islam - Volume 11, Nomor 1 (2020)

https://journal.walisongo.ac.id/index.php/economica 
Egi Arvian Firmansyah and Umar Ibrahim Manaf

\section{Methods}

This study employs an exploration method using a quantitative approach. First, data were collected and tested using statistical techniques, primarily for testing the hypothesis. The targeted population of this research is undergraduate students at faculty economics and business in three state universities in Bandung. Meanwhile, the sample was determined using a purposive sampling technique. The sample is undergraduate students of faculty of economics and business at Padjajaran University (Unpad), Indonesia University of Education (UPI), and students from the School of Business and Management at Bandung Institute of Technology (ITB). The measurement of the variables is explained in the table below:

Table 3. Operationalization of Variables

\begin{tabular}{|c|c|c|c|c|}
\hline Variable & Dimension & Indicator & Scale & $\begin{array}{l}\text { Number of } \\
\text { questions }\end{array}$ \\
\hline \multicolumn{5}{|c|}{ Dependent Variable (Y) } \\
\hline $\begin{array}{l}\text { Product } \\
\text { knowledge } \\
\text { (about Islamic } \\
\text { fintech } \\
\text { products) }\end{array}$ & $\begin{array}{l}\text { Product Knowledge } \\
\text { (Brucks 1985) }\end{array}$ & $\begin{array}{l}\text { - Subjective Knowledge } \\
\text { - Objective Knowledge } \\
\text { - Experience-based } \\
\text { Knowledge }\end{array}$ & \multirow{2}{*}{$\begin{array}{l}\pi \\
\stackrel{\pi}{Z} \\
\vdots \\
0\end{array}$} & 6 \\
\hline $\begin{array}{l}\text { Brand } \\
\text { Awareness } \\
\text { (Angsur brand } \\
\text { awareness) }\end{array}$ & $\begin{array}{l}\text { Brand Awareness } \\
\text { (Durianto, Sugiarto, } \\
\text { and Budiman 2004) }\end{array}$ & $\begin{array}{l}\text { - Top of mind } \\
\text { - Brand Recall } \\
\text { - Brand Recognition } \\
\text { - Unaware of brand }\end{array}$ & & 9 \\
\hline \multicolumn{5}{|c|}{ Independent Variable (X) } \\
\hline Age $\left(X_{1}\right)$ & Unit of time & $\begin{array}{l}\text { - The dummy variable } \\
\text { where } 0=\text { Age } \leq 20 \text { years, } \\
\text { and } 1=\text { Age }>20 \text { years. }\end{array}$ & \multirow{4}{*}{ 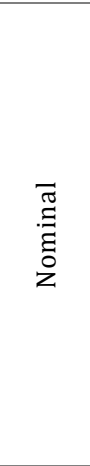 } & \multirow{4}{*}{4} \\
\hline Gender $\left(\mathrm{X}_{2}\right)$ & $\begin{array}{l}\text { Respondent's } \\
\text { gender. }\end{array}$ & $\begin{array}{l}\text { - Dummy variable where } 0 \\
=\text { male, and } 1=\text { female }\end{array}$ & & \\
\hline University $\left(\mathrm{X}_{3}\right)$ & $\begin{array}{l}\text { The origin of the } \\
\text { university in which } \\
\text { respondents obtain a } \\
\text { formal education. }\end{array}$ & $\begin{array}{l}\text { - Dummy variable where } 0 \\
\text { = Padjadjaran University, } \\
\text { and } 1 \text { = Non-Padjadjaran } \\
\text { University (UPI and ITB) }\end{array}$ & & \\
\hline $\begin{array}{l}\text { Monthly } \\
\text { expenses }\left(\mathrm{X}_{4}\right)\end{array}$ & $\begin{array}{l}\text { Total expenses paid } \\
\text { by respondents per } \\
\text { month in rupiah. }\end{array}$ & $\begin{array}{l}\text { - Dummy variable where } 0 \\
=\text { monthly expenses } \leq \text { IDR } \\
1,500,000, \text { and } 1= \\
\text { monthly expenses > IDR } \\
1,500,000\end{array}$ & & \\
\hline
\end{tabular}


The sampling technique used is the purposive sampling technique, a nonprobability sampling appropriate for specific criteria. We randomly selected participants based on unique characteristics, experiences, attitudes, or perceptions (Cooper and Schindler 2014). The data was collected by a questionnaire distributed to respondents. The data obtained through the questionnaire were transformed using the Rasch method, where we converted the ordinal data into interval data (Setiawan, Panduwangi, and Sumintono 2018). While the data analysis techniques used are the MannWhitney test and multiple regression.

\section{Result and discussion}

\section{Respondent demographics}

The sample quantity determined in this study was 376 respondents. Therefore, we disseminated the questionnaire to 376 students, and 316 respondents completed and returned the questionnaire. So, it can be said that the response rate of the questionnaire is $84 \%$. The characteristics of respondents based on the demographic factors are explained using the descriptive statistics shown in Table 4.

Table 4. Respondent characteristics based on demographic factors

\begin{tabular}{llll}
\hline Variable & Item & Frequency & Percentage \\
\hline Age & $\leq 20$ years & 153 & $48.4 \%$ \\
& $>$ 20 years & 163 & $51.6 \%$ \\
Gender & Male & 121 & $38.3 \%$ \\
& Female & 195 & $61.7 \%$ \\
University & Unpad & 169 & $56 \%$ \\
& UPI & 104 & $34 \%$ \\
\multirow{3}{*}{ Monthly Expenses } & ITB & 43 & $10 \%$ \\
& $\leq$ IDR 1,500,000 & 193 & $61.1 \%$ \\
& >IDR 1,500,000 & 123 & $38.9 \%$ \\
\hline
\end{tabular}

Source: Processed data, 2019

Economica: Jurnal Ekonomi Islam - Volume 11, Nomor 1 (2020) 
Egi Arvian Firmansyah and Umar Ibrahim Manaf

Of the 316 respondents, $51.6 \%$ are over 20 years old, and $48.4 \%$ are younger than 20. Based on gender, most of the respondents $(61.7 \%)$ are women. Furthermore, by university origin, the majority of respondents (56\%) are Unpad students. Based on monthly spending, most respondents (61.1\%) had a monthly expense of less than IDR 1,500,000. Only $38.9 \%$ of them had monthly spending of more than IDR 1,500,000. These amounts do not include housing renting fees, and they are appropriate with the cost of living in Bandung, primarily for university students.

\section{Knowledge of Islamic fintech products}

Product knowledge of Islamic fintech is presented in descriptive statistics described in Table 5.

The obtained data shows that more than half of the respondents (56.6\%) disagreed and strongly disagreed with a statement that they have sufficient knowledge about Islamic products. It means most of our respondents have minimal knowledge about Islamic fintech products. Therefore, Islamic fintech companies, government agencies, and other parties need to improve the understanding of millennials about Islamic fintech products.

Table 5. Respondent responses about the knowledge of Islamic fintech products

\begin{tabular}{lllllll}
\hline Question & $\begin{array}{l}\text { Total } \\
\text { number of } \\
\text { respondents }\end{array}$ & $\begin{array}{l}\text { Strongly } \\
\text { Disagree } \\
\text { (\%) }\end{array}$ & $\begin{array}{l}\text { Disagree } \\
\text { (\%) }\end{array}$ & $\begin{array}{l}\text { Agree } \\
\text { (\%) }\end{array}$ & $\begin{array}{l}\text { Strongly } \\
\text { Agree } \\
\text { (\%) }\end{array}$ & $\begin{array}{l}\text { Total } \\
\text { (\%) }\end{array}$ \\
\hline Q1 & 316 & $13.9 \%$ & $35.1 \%$ & $42.5 \%$ & $8.5 \%$ & $100 \%$ \\
Q2 & 316 & $18.4 \%$ & $39.2 \%$ & $35.4 \%$ & $7 \%$ & $100 \%$ \\
Q3 & 316 & $14.6 \%$ & $31 \%$ & $41.1 \%$ & $13.3 \%$ & $100 \%$ \\
Q4 & 316 & $42.4 \%$ & $32 \%$ & $19.3 \%$ & $6.3 \%$ & $100 \%$ \\
Average & 316 & $22.3 \%$ & $34.3 \%$ & $34.6 \%$ & $8.8 \%$ & $100 \%$ \\
\hline
\end{tabular}

Source: Processed data, 2019 
Table 6. Knowledge about Islamic fintech products

\begin{tabular}{lllllll}
\hline Question & $\begin{array}{l}\text { Total } \\
\text { number of } \\
\text { respondents }\end{array}$ & $\begin{array}{l}\text { Strongly } \\
\text { Disagree } \\
\text { (\%) }\end{array}$ & $\begin{array}{l}\text { Disagree } \\
\text { (\%) }\end{array}$ & $\begin{array}{l}\text { Agree } \\
\text { (\%) }\end{array}$ & $\begin{array}{l}\text { Strongly } \\
\text { Agree } \\
\text { (\%) }\end{array}$ & $\begin{array}{l}\text { Total } \\
\text { (\%) }\end{array}$ \\
\hline Q5 & 81 & $1.2 \%$ & $14.8 \%$ & $61.7 \%$ & $22.2 \%$ & $100 \%$ \\
Q6 & 313 & $13.7 \%$ & $33.2 \%$ & $42.5 \%$ & $10.5 \%$ & $100 \%$ \\
Average & 197 & $7.5 \%$ & $24 \%$ & $52.1 \%$ & $16.4 \%$ & $100 \%$ \\
\hline
\end{tabular}

Source: Processed data, 2019

Table 6. explains that from respondents who have ever used or been informed of the Islamic fintech services, most (68.5\%) agreed and strongly agreed that using Islamic fintech services is comfortable. They also pointed out that Islamic fintech companies provided satisfying services. However, around $31.5 \%$ of respondents perceived that Islamic fintech services are not entirely moving. Thus, it is homework for Islamic fintech firms to keep improving their services.

\section{Angsur brand awareness}

Brand awareness of Angsur brand is presented in descriptive statistics as shown in Table 7 as follows.

Table 7. Angsur brand awareness

\begin{tabular}{lllllll}
\hline Question & $\begin{array}{l}\text { Total } \\
\text { number of } \\
\text { respondents }\end{array}$ & $\begin{array}{l}\text { Strongly } \\
\text { Disagree } \\
\text { (\%) }\end{array}$ & $\begin{array}{l}\text { Disagree } \\
\text { (\%) }\end{array}$ & $\begin{array}{l}\text { Agree } \\
\text { (\%) }\end{array}$ & $\begin{array}{l}\text { Strongly } \\
\text { Agree } \\
\text { (\%) }\end{array}$ & $\begin{array}{l}\text { Total } \\
\text { (\%) }\end{array}$ \\
\hline Q1 & 316 & $35.4 \%$ & $41.8 \%$ & $19.9 \%$ & $2.8 \%$ & $100 \%$ \\
Q2 & 316 & $64.2 \%$ & $30.4 \%$ & $3.8 \%$ & $1.6 \%$ & $100 \%$ \\
Q3 & 316 & $45.9 \%$ & $30.1 \%$ & $17.7 \%$ & $6.3 \%$ & $100 \%$ \\
Q4 & 316 & $24.4 \%$ & $25.6 \%$ & $38.9 \%$ & $11.1 \%$ & $100 \%$ \\
Q5 & 316 & $48.1 \%$ & $30.1 \%$ & $19.3 \%$ & $2.5 \%$ & $100 \%$ \\
Q6 & 316 & $45.6 \%$ & $28.8 \%$ & $20.3 \%$ & $5.4 \%$ & $100 \%$ \\
Q7 & 316 & $50.3 \%$ & $35.8 \%$ & $11.7 \%$ & $2.2 \%$ & $100 \%$ \\
Q8 & 316 & $43 \%$ & $34.5 \%$ & $17.7 \%$ & $4.7 \%$ & $100 \%$ \\
Q9 & 316 & $45.6 \%$ & $30.4 \%$ & $20.3 \%$ & $3.8 \%$ & $100 \%$ \\
Average & 316 & $44.7 \%$ & $31.9 \%$ & $18.8 \%$ & $4.5 \%$ & $100 \%$ \\
\hline
\end{tabular}

Source: Processed data, 2019

Economica: Jurnal Ekonomi Islam - Volume 11, Nomor 1 (2020) 
Egi Arvian Firmansyah and Umar Ibrahim Manaf

Based on the acquired data, it can be interpreted that most respondents $(76.6 \%)$ did not have any awareness of the Angsur brand. It means that many millennials still do not know about Angsur, including the services that are provided. Therefore, Angsur must intensify its marketing strategies to increase brand awareness of the millennial generation, which is its target market.

\section{Mean difference of knowledge of Islamic fintech products and angsur brand awareness}

This research uses the Mann-Whitney test to analyze the mean difference in Islamic fintech products and brand awareness based on age, gender, university origin, and monthly spending of the respondents. Table 8 explains the average value of the knowledge of Islamic fintech products and Angsur brand awareness of each category. Table 8 also shows the Mann-Whitney test significance values. In the tests of Mann-Whitney, data from two groups may be stated to be significantly different if the Sig. Mann-Whitney < p-value (0.05). If the Sig. Mann-Whiney > p-value (0.05), then the two-group data is declared to have no significant difference.

Table 8. Results of mean-Whitney tests for knowledge about Islamic products

\begin{tabular}{|c|c|c|c|c|c|c|c|c|}
\hline & \multicolumn{2}{|c|}{ Age (years) } & \multicolumn{2}{|c|}{ Gender } & \multicolumn{2}{|c|}{ University } & \multicolumn{2}{|c|}{$\begin{array}{c}\text { Monthly Expenses } \\
\text { (millions) }\end{array}$} \\
\hline & $\leq 20$ & $>20$ & Male & Female & Unpad & $\begin{array}{l}\text { Non- } \\
\text { Unpad }\end{array}$ & $\leq 1,500,000$ & $>1,500,000$ \\
\hline $\begin{array}{l}\text { Average } \\
\text { Sig. }\end{array}$ & 0.074 & 0.164 & 0.087 & 0.141 & 0.107 & 0.136 & 0.134 & 0.099 \\
\hline $\begin{array}{l}\text { Mann- } \\
\text { Whitney } \\
\text { test }\end{array}$ & \multicolumn{2}{|c|}{0.259} & \multicolumn{2}{|c|}{0.645} & \multicolumn{2}{|c|}{0.839} & \multicolumn{2}{|c|}{0.391} \\
\hline \multicolumn{9}{|c|}{ Angsur Brand Awareness } \\
\hline & \multicolumn{2}{|c|}{ Age (years) } & \multicolumn{2}{|c|}{ Gender } & \multicolumn{2}{|c|}{ University } & \multicolumn{2}{|c|}{$\begin{array}{c}\text { Monthly Expenses } \\
\text { (millions) }\end{array}$} \\
\hline & $\leq 20$ & $>20$ & Male & Female & Unpad & $\begin{array}{l}\text { Non- } \\
\text { Unpad }\end{array}$ & $\leq 1,500,000$ & $>1,500,000$ \\
\hline $\begin{array}{l}\text { Average } \\
\text { Sig. }\end{array}$ & -0.150 & -0.188 & -0.181 & -0.163 & -0.101 & -0.249 & -0.179 & -0.154 \\
\hline $\begin{array}{l}\text { Mann- } \\
\text { Whitney } \\
\text { test }\end{array}$ & \multicolumn{2}{|c|}{0.688} & \multicolumn{2}{|c|}{0.876} & \multicolumn{2}{|c|}{0.033} & \multicolumn{2}{|c|}{0.791} \\
\hline
\end{tabular}

Source: Processed data, 2019 
Table 8 shows that, on average, the score of students aged more than 20 is higher than those younger than 20 years. Understandably, those who are a little bit older may have acquired more information about Islamic fintech products. We also found that female students tend to have better knowledge about Islamic fintech products than male students. Furthermore, non-Unpad students were found to be more knowledgeable about Islamic fintech products than Unpad students. Finally, undergraduate students with monthly expenditures less than IDR 1,500,000 tend to have better knowledge about Islamic fintech products than those who have monthly spending more than IDR 1,500,000. However, when we look at the Sig. values for all those four variables, the difference is not significant because they all have the sig values of more than 0.05 .

Regarding Angsur brand awareness, we found that age, gender, and monthly expenses are not significantly different among the two compared groups because of their Sig. values are more than 0.05 . Only considerably another university variable, because its Sig. value is less than 0.05 . We found that Unpad students tend to have a higher level of awareness of the Angsur brand.

The data processing results in this study illustrate that only the university variable distinguishes the awareness of the Angsur brand. The results of this study are different from the study of Lantara \& Kartini (2016). Lantara and Kartini (2016) found that there is a difference in financial literacy level (though it is not clearly stated as brand awareness) based on gender and income levels at undergraduate and postgraduate students at Gadjah Mada University (UGM). In addition, the results of this study do not support Che-ha, Hamzah, Sukor, said, \& Veeriah (2017) explaining that there is a significant difference in awareness of Islamic banking products among state university students in Malaysia, based on age and income. 


\section{Effect of age, gender, university and monthly expenses on the knowledge of Islamic fintech products}

In addition to identifying the knowledge level of Islamic fintech products and Angsur brand awareness, this research also examines whether demographic factors of respondents affect the knowledge. Thus, the first hypothesis in the study is as follows:

\section{Ha1: $\mathrm{B} 1 \neq \mathrm{b} 2 \neq \mathrm{b} 3 \neq \mathrm{b} 4 \neq 0$}

That hypothesis means a significant and simultaneous effect of age, gender, university, and monthly expense (X variables) on respondents' knowledge about Islamic fintech products ( $\mathrm{Y}$ variable). The test criterion is, if the F-value $>$ F-table, then $\mathrm{H} 1$ is accepted. If F-value $<$ F-table, then Ha1 cannot accepted. With a significance level of 0.05 and stated degrees of freedom (4;311), this study result shows that F-value is 0.310 , smaller than the F-table of 2.401. Thus, Ha1 cannot be accepted. It means that based on this research, there is no significant and simultaneous effect of age, gender, university, and monthly expenditure on the knowledge of respondents about Islamic fintech products. In other words, respondents' knowledge about Islamic fintech is not due to their age, gender, university origin, and monthly spending. Rather, the high knowledge can be due to respondents' internal motivation and exposure to technology (Darmansyah et al. 2020).

To test whether each independent variable contributes significantly to the knowledge (partial effect), we can see the following output table:

Table 9. Partial hypothesis test (t-test) of Islamic fintech products

\begin{tabular}{|c|c|c|c|c|c|}
\hline \multirow[t]{2}{*}{ Model } & \multicolumn{2}{|c|}{$\begin{array}{l}\text { Unstandardized } \\
\text { Coefficients }\end{array}$} & \multirow{2}{*}{$\begin{array}{c}\text { Standardized } \\
\text { Coefficient } \\
\text { Beta }\end{array}$} & \multirow[t]{2}{*}{$\mathrm{t}$} & \multirow[t]{2}{*}{ Sig. } \\
\hline & B & Std. Error & & & \\
\hline 1 (Constant) & 0.036 & 0.119 & & 0.305 & 0.761 \\
\hline Age & 0.095 & 0.103 & 0.053 & 0.920 & 0.358 \\
\hline Gender & 0.048 & 0.106 & 0.026 & 0.449 & 0.653 \\
\hline University & 0.035 & 0.104 & 0.019 & 0.334 & 0.738 \\
\hline Monthly Expenditure & -0.026 & 0.105 & -0.014 & -0.252 & 0.801 \\
\hline
\end{tabular}

a. Dependent Variable: Product Knowledge

Source: Processed data, 2019 
Table 9 shows that all four independent variables have the Sig. values larger than 0.05 . Therefore, it can be seen that, partially, age, gender, university, and monthly expenditures do not significantly affect respondents' knowledge level about Islamic fintech products. This result corresponds to the results of the simultaneous hypothesis testing outlined earlier.

\section{Effect of age, gender, university and monthly expenses on angsur brand awareness}

The second hypothesis in this study is as follows:

$$
\text { Ha2: } \mathrm{B} 1 \neq \mathrm{b} 2 \neq \mathrm{b} 3 \neq \mathrm{b} 4 \neq 0 \text {, }
$$

That means a significant and simultaneous effect of age, gender, university, and monthly spending on respondents' awareness of the Angsur brand. Therefore, the test criterion is, if the F-value > F-table, then Ha2 is accepted. However, if F-value < F-table, then $\mathrm{H} 12$ cannot be accepted. For example, with a significance level of 0.05 and the stated degree of freedom (4;311), it is known that F-value is 0.907 and F-table is 2.401. As a result, Ha2 is rejected, which means that there is no significant and simultaneous effect of age, gender, university, and monthly spending on respondent awareness of the Angsur brand. Then, to identify whether each independent variable has a significant effect on the dependent variable, we can see the following output table:

Table 10. Partial hypothesis test (t-test) of Angsur brand awareness

\begin{tabular}{|c|c|c|c|c|c|}
\hline \multirow[t]{2}{*}{ Model } & \multicolumn{2}{|c|}{$\begin{array}{l}\text { Unstandardized } \\
\text { Coefficients }\end{array}$} & \multirow{2}{*}{$\begin{array}{c}\text { Standardized } \\
\text { Coefficient } \\
\text { Beta }\end{array}$} & \multirow[t]{2}{*}{$\mathbf{t}$} & \multirow[t]{2}{*}{ Sig. } \\
\hline & B & $\begin{array}{l}\text { Std. } \\
\text { Error }\end{array}$ & & & \\
\hline 1 (Constant) & -0.098 & 0.101 & & -0.973 & 0.331 \\
\hline Age & -0.059 & 0.087 & -0.038 & -0.672 & 0.502 \\
\hline Gender & 0.041 & 0.090 & 0.026 & 0.456 & 0.649 \\
\hline University & -0.160 & 0.088 & -0.105 & -1.821 & 0.070 \\
\hline Monthly Expenditure & 0.021 & 0.089 & 0.013 & 0.233 & 0.816 \\
\hline
\end{tabular}

Source: Processed data, 2019

Economica: Jurnal Ekonomi Islam - Volume 11, Nomor 1 (2020) https://journal.walisongo.ac.id/index.php/economica 
Egi Arvian Firmansyah and Umar Ibrahim Manaf

According to Table 10, it is known that all dummy independent variables have the sig. value larger than 0.05 . Therefore, it can be understood that, partially, age, gender, university origin, and monthly expenditures do not significantly impact the Angsur brand awareness. This result also corresponds to the results of the simultaneous hypothesis testing described earlier. However, if the study uses a 10\% significance level (0.10), the university variable significantly affects Angsur brand awareness.

\section{The opinion of respondents on the fintech material on the course}

\section{syllabus}

Descriptive statistics are used to portray respondents' answers to three questions related to their opinions on the academic syllabus and willingness to gain knowledge of Islamic fintech. It is essential to explore these matters since students of state universities are often viewed as having a higher exposure to Sharia finance, as the management of their institutions is often seen as good. Here is a description of the student's answers to the three questions asked.

Based on Table 11, it can be seen that the majority of respondents (68\%) strongly disagreed and disagreed that the lessons or materials of Islamic fintech were included in their academic syllabus. Only the remaining 31.9\% of respondents agreed and strongly agreed with that statement. It suggests that a top-down (university to student) approach is not shared within the campus. Hence, it can be understood that the student's Islamic financial literacy is

Table 11. Respondent responses on Islamic fintech syllabus

\begin{tabular}{ccccccc}
\hline Question & $\begin{array}{c}\text { Total } \\
\text { number of } \\
\text { respondents }\end{array}$ & $\begin{array}{c}\text { Strongly } \\
\text { Disagree } \\
\mathbf{( \% )}\end{array}$ & $\begin{array}{c}\text { Disagree } \\
\mathbf{( \% )}\end{array}$ & $\begin{array}{c}\text { Agree } \\
\mathbf{( \% )}\end{array}$ & $\begin{array}{c}\text { Strongly } \\
\text { Agree } \\
\text { (\%) }\end{array}$ & $\begin{array}{c}\text { Total } \\
\text { (\%) }\end{array}$ \\
\hline Q1 & 316 & $33.5 \%$ & $34.5 \%$ & $20.9 \%$ & $11.1 \%$ & $100 \%$ \\
Q2 & 316 & $3.5 \%$ & $8.2 \%$ & $35.1 \%$ & $53.2 \%$ & $100 \%$ \\
Q3 & 316 & $7.9 \%$ & $20.3 \%$ & $40.8 \%$ & $31 \%$ & $100 \%$ \\
\hline
\end{tabular}

Source: Processed data, 2019 
relatively low. This also applies in Islamic universities, as discussed in previous studies (Said and Amiruddin 2017). Moreover, financial literacy highly affects students using products offered by Islamic financial institutions (Batubara, Pulungan, and Yenty 2020).

Then, in the second question, we can see that most respondents (88.3\%) strongly agreed and agreed that students studying economics and business studies should get the proper knowledge about Islamic fintech. This result is a valuable input for managers in various business schools or business faculties. Business schools can bring Sharia economic courses into their higher education curriculum because Islamic finance is potential (Hanif, 2016). Indonesia's chance to be the hub of Islamic finance is also high (Yuniarti 2021). In addition, it is also indicated that the economic and business faculties can also consider opening an Islamic economic study program so that students' exposure to Islamic finance within those faculties can improve.

In the third or final question, we can note that most respondents (71.8\%) agreed and strongly agreed that students studying economics and business studies should take courses on Islamic fintech. While the remaining or $28.2 \%$ of respondents disagreed and strongly disagreed with that idea. Again, this result reiterates the need to introduce and promote Islamic fintech courses or materials to millennial generations, primarily business and economics students.

\section{Conclusion}

This study investigates the level of product knowledge and Angsur brand of undergraduate students (S1) at economics and business faculties in three state universities in Bandung. First, this research can conclude that respondents' Islamic fintech knowledge and Angsur brand awareness are relatively low. Second, respondents' knowledge about Islamic fintech products is not significantly different, seen by their age, gender, university, and 
monthly spending. Third, Angsur's brand awareness of the respondents is not considerably different either, seen by their age, gender, and monthly expenses. However, this result is significantly different based on university if the significance value is increased to ten percent. Fourth, age, gender, university, and monthly spending do not significantly affect the respondents' knowledge about Islamic fintech products. Fifth, age, gender, university origin, and monthly expenses have no significant influence on Angsur's brand awareness of the respondents. Sixth, respondents generally agreed that Islamic fintech is not available in their academic syllabus. They also put forward that students studying economics and business should get the proper knowledge about Islamic fintech. In addition, students studying economics and business should take the Islamic fintech course because it is perceived as an introductory course in preparing for their future.

This research implies that, first, Angsur should refine its marketing strategies to improve students' brand awareness, given that they are Angsur's target market. In addition, Angsur may also work together more intensively with students at various universities in Angsur Student Partner program so that many students from those universities will be more aware of the existence and features of the Angsur brand. The second implication is that students are expected to be more active in searching for Islamic fintech knowledge. Students' activeness can be obtained through joining seminars, reading journal articles, online articles, and relevant information on social media. Economic and business students should be more educated and familiar with Islamic fintech, which gains popularity in today's digital age. Third, universities, especially their economics and business faculties, are expected to perfect student academic curriculum by adding courses or materials related to Islamic fintech. By introducing Islamic fintech in their academic curriculum, undergraduate students will gain the proper knowledge about Islamic fintech as preparation before jumping into the Islamic fintech sector and contributing to enhancing Islamic fintech in society. Fourth, due to financial, energy, and 
time constraints, this research is limited as it only involves undergraduate students majoring in business and economics at three state universities in Bandung (Unpad, UPI, and ITB). Thus, further research can expand the research scope by including students from other universities in Indonesia. Besides, further studies may add other independent variables that are considered to significantly impact the Islamic fintech knowledge and brand awareness of Islamic fintech brands.

\section{References}

Aaker, David A. 1997. Manajemen Ekuitas Merek: Memanfaatkan Nilai Dari Suatu Merek. Jakarta: Spektrum. https://doi.org/1037/00332909.I26.1.78.

Anikina, I.D., A.V. Gukova, A.A. Golodova, and A.A. Chekalkina. 2016. "Methodological Aspects of Prioritization of Financial Tools for Stimulation of Innovative Activities." European Research Studies Journal XIX (Issue 2): 100-112. https://doi.org/10.35808/ersj/525.

APJII. 2017. "Penetrasi \& Perilaku Pengguna Internet Indonesia." Apjii 2018 (31 August 2018): Hasil Survey.

Arner, Douglas W., Janos Nathan Barberis, and Ross P. Buckley. 2015. "The Evolution of Fintech: A New Post-Crisis Paradigm?" SSRN Electronic Journal. https://doi.org/10.2139/ssrn.2676553.

Bachdar, Saviq. 2018. "Jangan Heran, Literasi Keuangan Mahasiswa Indonesia Masih Rendah." Marketeers. 2018.

Batubara, Soulthan Saladin, Delyana Rahmawany Pulungan, and Musfa Yenty. 2020. "Analisis Determinan Minat Mahasiswa Dalam Menggunakan Lembaga Keuangan Syariah." Jurnal Riset Akuntansi Dan Bisnis 20 (1): 2337. https://doi.org/10.30596/jrab.v20i1.4757.

Brucks, Merrie. 1985. “The Effects of Product Class Knowledge on Information Search Behavior." Journal of Consumer Research 12 (1): 1. https://doi.org/10.1086/209031.

Chang, Chingching. 2004. "The Interplay Of Product Class Knowledge And Trial Experience In Attitude Formation." Journal of Advertising 33 (1): 83 92. https://doi.org/10.1080/00913367.2004.10639156. 
Egi Arvian Firmansyah and Umar Ibrahim Manaf

Che-ha, Norbani, Zalfa Laili Hamzah, Mohd Edil Abd Sukor, Saad Mohd Said, and Komala Veeriah. 2017. "Profiling Islamic Banking Customers: Does Product Awareness Matter?" Advances in Islamic Finance, Marketing, and Management, 223-43. https://doi.org/10.1108/9781786358981.

Chen, Kevin. 2018. "Financial Innovation and Technology Firms: A Smart New World with Machines." In , 279-92. https://doi.org/10.1108/S1571038620180000025012.

Cooper, Donald R, and Pamela S Schindler. 2014. Business Research Methods. 12th ed. New York: Mc-Graw Hill/Irwin.

Darmansyah, Bayu Arie Fianto, Achsania Hendratmi, and Primandanu Febriyan Aziz. 2020. "Factors Determining Behavioral Intentions to Use Islamic Financial Technology: Three Competing Models." Journal of Islamic Marketing, no. August 2019. https://doi.org/10.1108/JIMA-122019-0252.

Departemen Agama RI. 2007. Al-Kafi Mushaf Al-Quran. 1st ed. Bandung: CV Penerbit Diponegoro. https://doi.org/.1037//0033-2909.I26.1.78.

Dewan Syariah Nasional. 2017. "Fatwa DSN-MUI Tentang Uang Elektronik Syariah," no. 19: 12.

Dharmesh, Mistry. 2016. "Racing From Digital Engagement To Customer Intimacy." Temenos.

DinarStandard. 2021. "Global Islamic Fintech Report."

DSN-MUI. 2018. “Fatwa Dewan Syariah Nasional-Majelis Ulama Indonesia No: 117/Dsn-Mui/Ii/2018 Tentang Layanan Pembiayaan Berbasis Teknologi Informasi Berdasarkan Prinsip Syariah."

Durianto, Darmadi, Sugiarto, and Lie Joko Budiman. 2004. Brand Equity Ten Strategi Memimpin Pasar. Jakarta: PT Gramedia Pustaka Utama.

Firmansyah, Egi Arvian, and Mokhamad Anwar. 2019. "Islamic Financial Technology (Fintech): Its Challenges and Prospect." In Advances in Social Science, Education and Humanities Research (ASSEHR), 216:52-58. https://doi.org/10.2991/assdg-18.2019.5.

Gunadi, Widyo. 2019. "Digital Finance Innovation Roadmap and Regulatory Framework Table of Contents." Seminar Nasional Fintech Syariah.

Hidayat, Ali Akhmad Noor. 2018. "Fintech Syariah, Indonesia Dinilai Lebih Unggul Dari Malaysia," July 2018. 
Kalmykova, Ekaterina, and Anna Ryabova. 2016. "FinTech Market Development Perspectives." SHS Web of Conferences 28: 4-8. https://doi.org/10.1051/shsconf/20162801051.

Keller, Kevin Lane. 2013. Strategic Brand Management. 4th ed. Pearson Education Inc. https://doi.org/10.1057/bm.1998.36.

Kementrian Komunikasi Dan Informatika Ri. 2017. "Data \& Statistik Kominfo." KPMG. 2017. "Finance in Indonesia : Set for a New Path ?," no. September.

Lantara, I Wayan Nuka, and Ni Ketut Rai Kartini. 2016. "Financial Literacy Among University Students: Empirical Evidence From Indonesia." Journal of Indonesian Economy and Business 29 (3): 247-56. https://doi.org/10.22146/jieb.10314.

Laucereno, Sylke Febrina. 2018. "Fintech Bisa Berpotensi Tingkatkan PDB Rp 25 Triliun," August 2018.

Lin, Long-Yi, and Chun-Shuo Chen. 2006. "The Influence of the Country-ofOrigin Image, Product Knowledge and Product Involvement on Consumer Purchase Decisions: An Empirical Study of Insurance and Catering Services in Taiwan." Journal of Consumer Marketing. https://doi.org/10.17265/1537-1506/2011.08.004.

Maudhody, Achmad. 2017. "OJK Gandeng Mahasiswa Jadi Agen Edukasi," October 2017.

Mohamed, Hazik, and Hassnian Ali. 2019. Blockchain, Fintech, and Islamic Finance. Boston/ Berlin: Walter de Gruyter Inc.

Nicoletti, Bernardo. 2017. The Future of Fintech. Palgrave Studies in Financial Services Technology. Springer Nature. https://doi.org/10.1007/978-14842-2949-1_10.

OJK. 2017. Kajian Perlindungan Konsumen Sektor Jasa Keuangan: Perlindungan Konsumen Pada Fintech. Jakarta: Departemen Perlindungan Konsumen.

Oxford Dictionaries. n.d. "Fintech | Definition of Fintech in English by Oxford Dictionaries."

Qolbi, Nur. 2018. "Fintech Syariah Telah Lampui Target Penyaluran Dana 2018." 2018.

Rohmati, Dani, Rachmasari Anggraini, and Tika Widiastuti. 2018. "Maqāṣid AlSharīah Sebagai Landasan Dasar Ekonomi Islam." Economica: Jurnal 
Egi Arvian Firmansyah and Umar Ibrahim Manaf

Ekonomi Islam $\quad 9 \quad 295$. https://doi.org/10.21580/economica.2018.9.2.2051.

Rusydiana, Aam Slamet. 2018. "Developing Islamic Financial Technology in Indonesia." Hasanuddin Economics and Business Review 2 (2): 143-52. https://doi.org/10.26487/hebr.v.

Said, Salmah, and Andi Muhammad Ali Amiruddin. 2017. "Literasi Keuangan Syariah Di Perguruan Tinggi Keagamaan Islam (Studi Kasus UIN Alauddin Makasar)." Al-Ulum 17 (1): 44-64. https://doi.org/10.9744/jmk.17.1.76.

Sandy, Kunthi Fahmar. 2018. "Fintech Syariah Tingkatkan Pasar Keuangan Domestik," December 2018.

Setiawan, Budi, Morita Panduwangi, and Bambang Sumintono. 2018. "A Rasch Analysis of the Community's Reference for Different Attributes of Islamic Banks in Indonesia." International Journal of Social Economics. https://doi.org/10.1108/IJSE-07-2017-0294.

Shimp, Terence A. 2003. Periklanan Promosi: Aspek Tambahan Komunikasi Pemasaran Terpadu. Jakarta: Erlangga.

Sumarwan, Ujang. 2011. Perilaku Konsumen: Teori Dan Penerapannya Dalam Pemasaran. Jakarta: PT Ghalia Indonesia.

Teja, Adrian. 2017. "Indonesian Fintech Business: New Innovations or Foster and Collaborate in Business Ecosystems?" The Asian Journal of Technology Management (AJTM) $10 \quad$ (1): 10-18. http://journal.sbm.itb.ac.id/index.php/ajtm/article/view/2134.

Wahyudi. 2017. "Pentingnya Mahasiswa Dalam Tingkatkan Literasi Keuangan." Okezone News, February 2017.

Wasyith, Wasyith. 2017. "Beyond Banking: Revitalisasi Maqāṣid Dalam Perbankan Syariah." Economica: Jurnal Ekonomi Islam 8 (1): 1. https://doi.org/10.21580/economica.2017.8.1.1823.

Yuniarti, Fauziah Rizki. 2021. "Indonesia Could Be Asia's next Islamic Finance Hub - Opinion - The Jakarta Post." Academia Opinion - The Jakarta Post. 2021. 